\title{
WELLENS' SYNDROME: FOCUS ON DIAGNOSIS AND CHOICE OF MYOCARDIAL REVASCULARIZATION STRATEGY
}

\author{
N.M. Seredyuk ${ }^{1}$, V.N. Seredyuk ${ }^{2}$, Ya.L. Vandzhura ${ }^{1}$, O.Z. Skakun ${ }^{1}$, V.V. Parakhoniak ${ }^{3}$
}

${ }^{1}$ Department of Internal Medicine No 2 and Nursing, Ivano-Frankivsk National Medical University, Ivano-Frankivsk, Ukraine

${ }^{2}$ Department of Internal Medicine of the Faculty of Dentistry named after M.M. Berezhnytsky, Ivano-Frankivsk National Medical University, Ivano-Frankivsk, Ukraine

${ }^{3}$ St. Luke's Medical and Diagnostic Center, Ivano-Frankivsk, Ukraine E-mail: seredyuknestor@gmail.com

\author{
СИНДРОМ WЕLLENS': У ФОКУСІ ДІАГНОСТИКА ТА ВИБІР СТРАТЕГІЇ \\ РЕВАСКУЛЯРИЗАЦІї МІОКАРДА \\ Н.М. Середюк ${ }^{1}$, В.Н. Середюк ${ }^{2}$, Я.Л. Ванджура ${ }^{1}$, О.3. Скакун ${ }^{1}$, В.В. Парахоняк ${ }^{3}$ \\ ${ }^{1}$ Кафедра внутрішньої медицини №2 та медсестринства, \\ Івано-Франківський національний медичний університет, Івано-Франківськ, Україна \\ 2 Кафедра внутрішньої медицини стоматологічного факультету імені М.М. Бережницького, \\ Івано-Франківський національний медичний університет, Івано-Франківськ, Україна \\ 3 Лікувально-діагностичний центр святого Луки, Івано-Франківськ, Україна
}

\begin{abstract}
Wellens' syndrome is an extremely relevant issue in modern cardiology. Wellens' syndrome is quite often untimely diagnosed, and the patient's management is the same as in case of unstable angina. Since without myocardial revascularization, widespread myocardial infarction develops within the following days or weeks, myocardial revascularization is needed as soon as possible. Characteristic changes on the electrocardiogram in case of Wellens' syndrome include biphasic (type A) or inverted (type B) T waves in leads V2-V3, which sometimes are seen in other precordial leads. There must be a history of recent angina in addition to these electrocardiogram changes. Troponin is usually negative; however, it can be slightly elevated. Sometimes, patients with classic electrocardiogram changes and clinical picture typical for Wellens' syndrome do not show hemodynamically significant stenosis of the left anterior descending artery typical for this syndrome. In such cases, "pseudo-Wellens' syndrome" is observed. Three cases of angiographically confirmed Wellens' syndrome and one case of pseudoWellens' syndrome are presented in this paper. All the patients with Wellens' syndrome had significant lesions of the left anterior descending artery. One patient had a triple-vessel lesion, and the other two had a single-vessel lesion. Troponin I was within normal limits in one patient, and slightly elevated and in the other two. These patients underwent successful myocardial revascularization (percutaneous coronary intervention); pharmacological therapy was prescribed.

Keywords: Wellens'Syndrome; Left Anterior Descending Artery; Myocardial Infarction; Revascularization; Percutaneous Coronary Intervention.

Резюме. Синдром Wellens' $є$ надзвичайно актуальним питання сучасної кардіології. Досить часто у реальній клінічній практиці трапляються випадки невчасної діагностики синдрому Wellens', а тактика ведення пацієнта є такою як при нестабільній стенокардії. Зважаючи на те, що у найближчі декілька днів або тижнів без реваскуляризації міокарда розвивається інфаркт міокарда із залученням багатьох сегментів лівого шлуночка, потрібно провести якомога швидше реваскуляризацію міокарда. При синдромі Wellens' характерними змінами на ЕКГ є двофазні (тип A) або інвертовані (тип В) зубці Т у відведеннях $\mathrm{V}_{2}-\mathrm{V}_{3}$, які іноді поширюються й на інші грудні відведення. Важливо, що крім цих змін повинен бути напад ангіонозного болю у анамнезі. Тропонін зазвичай негативний, але іноді може бути дещо вищим норми. Разом з тим у деяких пацієнтів із класичними змінами на ЕКГ та клінічною картиною, характерною для синдрому Wellens' при коронароангіографії не виявляють характерного для цього синдрому гемодинамічно значимого стенозу передньої міжшлуночкової гілки лівої коронарної артерії. У таких випадках йдеться про pseudo-Wellens' syndrome. У статті описано 3 випадки синдрому Wellens', підтверджених ангіографічно та один випадок pseudo-Wellens' syndrome. У всіх пацієнтів із синдромом Wellens' виявлено ураження передньої міжшлуночкової гілки лівої коронарної артерії. У одного пацієнта спостерігалося трьохсудинне ураження, у двох інших - односудинне. Тропонін у одного пацієнта був у межах норми, а у двох інших дещо перевищував норму. Цим пацієнтам проведено успішно реваскуляризацію міокарда шляхом стентування ураженого проксимального сегемнта передньої міжшлуночкової гілки лівої коронарної артерії, а також призначено медикаментозне лікування.
\end{abstract}

Ключові слова: Синдром Wellens', передня міжшлуночкова гілка лівой коронарної артеріӥ, інфаркт міокарда, реваскуляризація, стентування.

Problem Statement and Analysis of the Latest Research

In the English literature, Wellens' syndrome is also known as "acute coronary T-wave syndrome" or "sign of left anterior descending artery (LAD) disease" [1]. This syndrome occurs in $14-18 \%$ of patients hospitalized with a diagnosis of unstable angina [2]. Wellens' syndrome was first described by physicians de Zwaan C, Wellens HJ and colleagues [3], who had analyzed 145 cases of non-revascularized patients hospitalized for unstable angina with biphasic $\mathrm{T}$ waves in leads
V2-V3 and identified such patients as those having a unique pattern. In $75 \%$ of cases of unstable angina, a variant of which was Wellens' syndrome, a myocardial infarction was found to occur. The meantime of myocardial infarction development is 8.5 days after the onset of unstable angina $[3,4]$. The authors noted an increase in cardiac troponin levels in $12 \%$ of patients only and the level of biomarker activity was never elevated more than twice above the normal values [5].

The following signs are considered as diagnostic criteria 
for Wellens' syndrome [4]:

-T-wave inversion in leads V2 and V3 (it is possible in leads V1, $\mathrm{V} 4, \mathrm{~V} 5, \mathrm{~V} 6$ as well) or biphasic $\mathrm{T}$ waves (the ascending part is positive, the descending part is negative) in leads V2 and V3;

- isoelectric or slightly elevated $(<1 \mathrm{~mm})$ ST segment;

- preserved R-wave progression in the precordial leads (from $\mathrm{V} 1$ to V4) and the absence of pathological Q waves in the precordial leads;

- recent angina;

- persistence of the electrocardiogram (ECG) pattern after chest pain disappeared;

- normal or only slightly elevated levels of cardiac biomarkers.

Subsequently, the authors concluded that these signs should be supplemented by the results of coronary angiography, in with $>50 \%$ obstruction of the proximal LAD is found. The presence of critical stenosis of the proximal LAD is required to confirm the diagnosis of Wellens' syndrome. In the absence of this sign, "pseudo-Wellens' syndrome" is diagnosed [6].

There are only a few publications about the benefits of using speckle-tracking echocardiography for early detection of segmental contractility impairment, longitudinal strain, time to peak longitudinal strain, the postsystolic index, and the wall motion score index (WMSI).

The principle of choosing the management strategy for patients with Wellens' syndrome is unclear as well. Three scenarios of the doctor's tactic in diagnosing this syndrome are discussed: percutaneous coronary intervention (PCI), coronary artery bypass grafting (CABG), and drug therapy alone. According to the European Society of Cardiology(ESC) 2018 guideline, both PCI and CABG (IA class and level of evidence for both revascularization strategies) may be recommended for patients with non-ST segment elevation acute coronary syndrome and LAD stenosis/occlusion. Drug therapy may initially provide only symptomatic relief; however, Wellens' syndrome is typically followed by widespread myocardial infarction of the anterior and lateral walls of the left ventricle, which can result in death or severe left ventricular systolic dysfunction.

We present three case reports of Wellens' syndrome diagnosed by ECG and clinical features later confirmed by coronary angiography.

\section{Case Report 1}

A 43-year-old patient $\mathrm{D}$. was admitted to the hospital due to intense chest pain at rest lasting 30 minutes and radiating to both arms. An ECG was recorded and an inversion of the T waves in leads V2-V5 and a slight elevation of the ST segment in lead V2 were found (Fig. 1). Wellens' syndrome type B was diagnosed. The patient was referred to coronary angiography, which revealed subocclusion $(95 \%)$ of the mid LAD (thrombolysis in myocardial infarction (TIMI) flow grade 1), $50 \%$ stenosis of the posterior descending artery, and 75\% stenosis of the proximal circumflex artery (TIMI-2) (Fig. 2). The troponin level was $0.613 \mathrm{ng} / \mathrm{ml}$ (normal value is $<0.5 \mathrm{ng} / \mathrm{ml}$ ). Ad hoc stent implantation into the proximal LAD was performed using the Resolute Integrity drug eluting stent (DES) (4.0-22.0 $\mathrm{mm}$ ) with the result of TIMI-3. Pharmacological treatment was prescribed. PCI of the circumflex artery was recommended as a planned procedure.

\section{Case Report 2}

A 57-year-old patient $V$. had been complaining of intermittent chest pain for the last four days before his visit to a doctor. The pain occurred more often with increasing blood pressure. Nitroglycerin and validol relieved pain. After the ECG was recorded (Fig. 3) and Wellens' syndrome type A was diagnosed, the patient was urgently hospitalized. However, he refused to undergo coronary angiography and left the hospital. The level of troponin I was within normal limits. Over the next two days, the pain became more intense (optimal pharmacological therapy was prescribed), and the patient was re-admitted to the hospital. Coronary angiography was performed. There were detected subocclusion (95\%) of the proximal LAD (TIMI-1) and stenosis $(50 \%)$ of the mid right coronary artery (TIMI-2) (Fig. 4). Stent implantation was performed.

\section{Case Report 3}

A 69-year-old patient M. had been complaining of the intermittent chest pain with irradiation to the left arm for the last three days before he visited a doctor. The pain occurred both at rest and during exercises. The ECG revealed biphasic $\mathrm{T}$ waves in leads V2-V4, as well as T-wave inversion in leads I and aVL (Fig. 5). The level of troponin I was $1.2 \mathrm{ng} / \mathrm{ml}$. Coronary angiography revealed subocclusion (95\%) of the LAD, TIMI 0-1. (Fig. 6). There was performed stent (Resolute Integrity DES 4.0-34.0 mm) implantation in the LAD with complete blood flow restoration (TIMI-3). Pharmacological treatment was prescribed.

\section{Discussion}

In a study conducted by Stankovic I, et al., 2017, Wellens' syndrome was diagnosed in $37.0 \%$ of patients with critical stenosis of the LAD; among them, $60.0 \%$ were men, $37.0 \%$ were smokers, $97.0 \%$ had hypertension, $83.0 \%$ had dyslipidemia. A family history of coronary artery disease was noted in $46.0 \%$ of patients with Wellens' syndrome. Single-vessel lesion was verified in $31 \%$ of patients, double-vessel lesion was verified in $37 \%$ of patients, and triple-vessel lesion was found in $31 \%$ of patients [8].

In all three cases presented above, critical stenosis of the LAD was verified angiographically.

Myocardial infarction is known to develop in $75 \%$ of nonrevascularized patients with ECG changes typical for Wellen's syndrome within several weeks [3]. According to the group of researchers who, in 1989, carried out the study involving 1,260 patients, patients with Wellens' syndrome have a very high risk of developing myocardial infarction and should, therefore, be referred for emergency coronary angiography and ad hoc myocardial revascularization. According to the same authors, among all the patients with a typical Wellens' ECG pattern, critical stenosis of the LAD with partial collateral blood flow was detected in $75.0 \%$ of patients [5]. The Wellens' ECG pattern should be differentiated from the de Winter ECG pattern. In the original study, the de Winter pattern was found in 30 out of 1,532 patients $(2 \%)$ with confirmed LAD occlusion [9]. The T wave in de Winter syndrome is high and acute (hyperacute $\mathrm{T}$ waves) [10].

There is still no consensus on the origin of T wave changes in Wellens' syndrome, especially the main ECG feature of this syndrome - biphasic and inverted T waves. Such changes are thought to occur due to the short-term episodes of myocardial ischemia. However, they are not associated with myocardial necrosis or scarring. This is evidenced by the absence of pathological Q waves on the ECG. However, this issue can be solved by analyzing the longitudinal, radial strain, and twist/ torsion of the left ventricle during speckle-tracking 


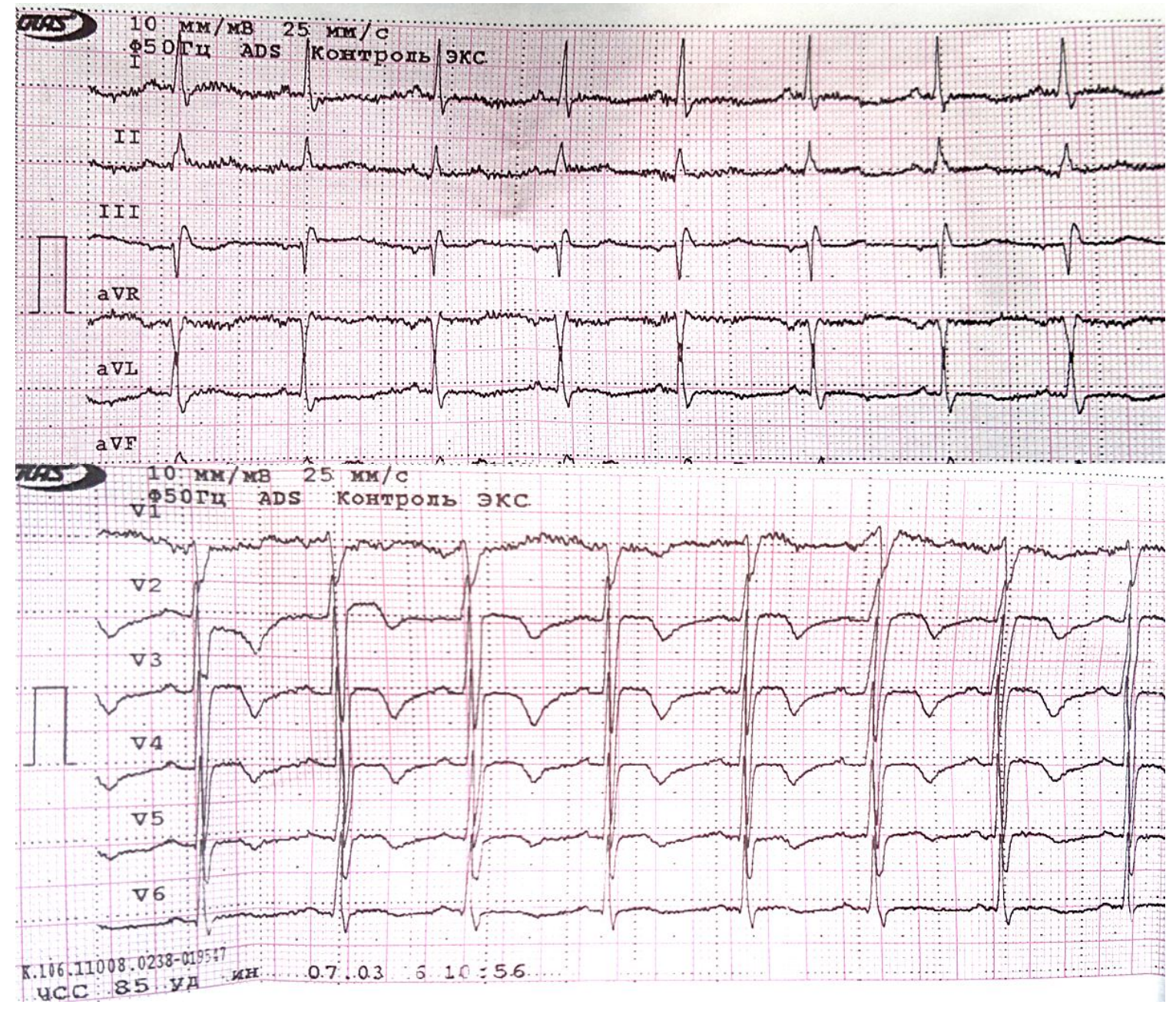

Fig. 1. ECG. T-wave inversion in leads V2-V5 and slight ST segment elevation in lead V2
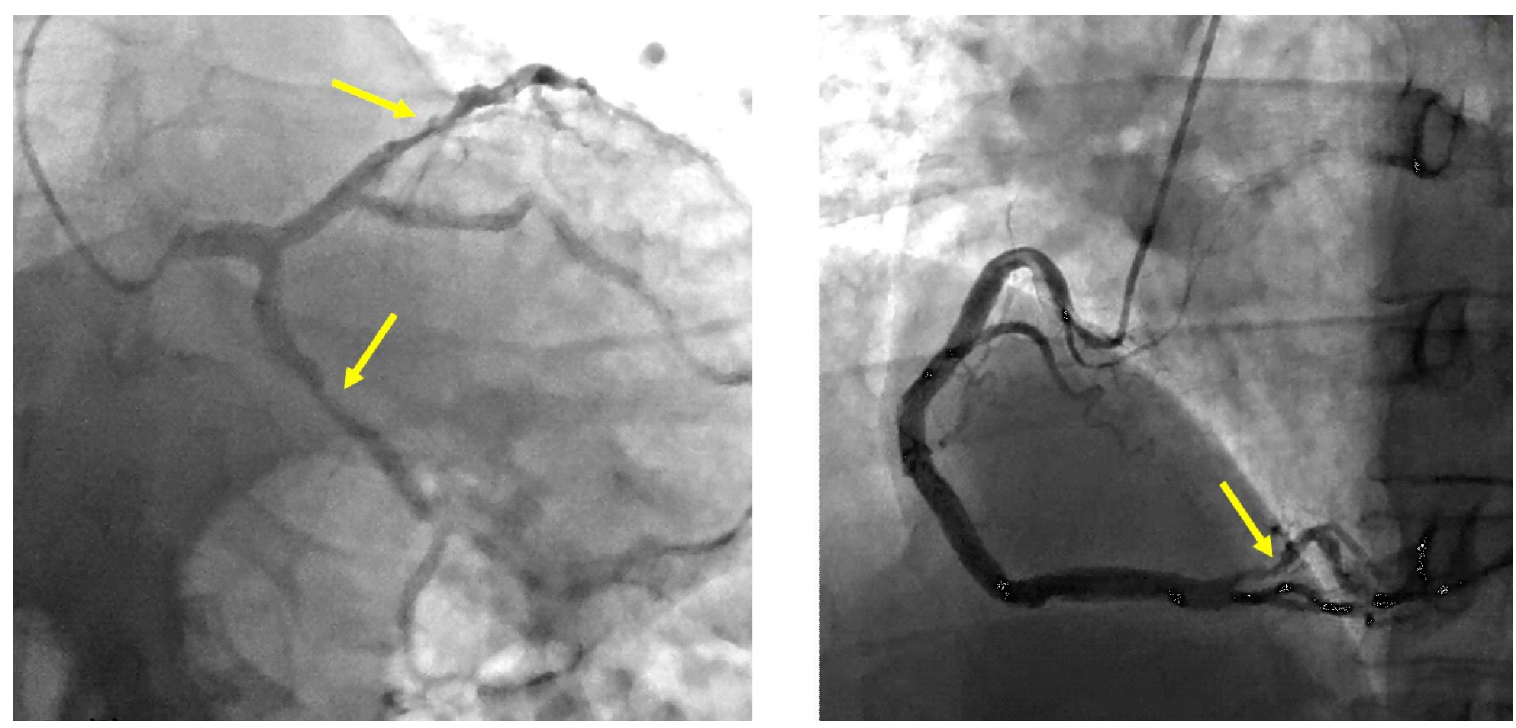

Fig. 2. Coronary angiography. Subocclusion $(95 \%)$ of the mid segment of the left coronary artery, $50 \%$ stenosis of the posterior descending artery and $\mathbf{7 5 \%}$ stenosis of the proximal circumflex artery

Yellow arrows indicate stenoses 

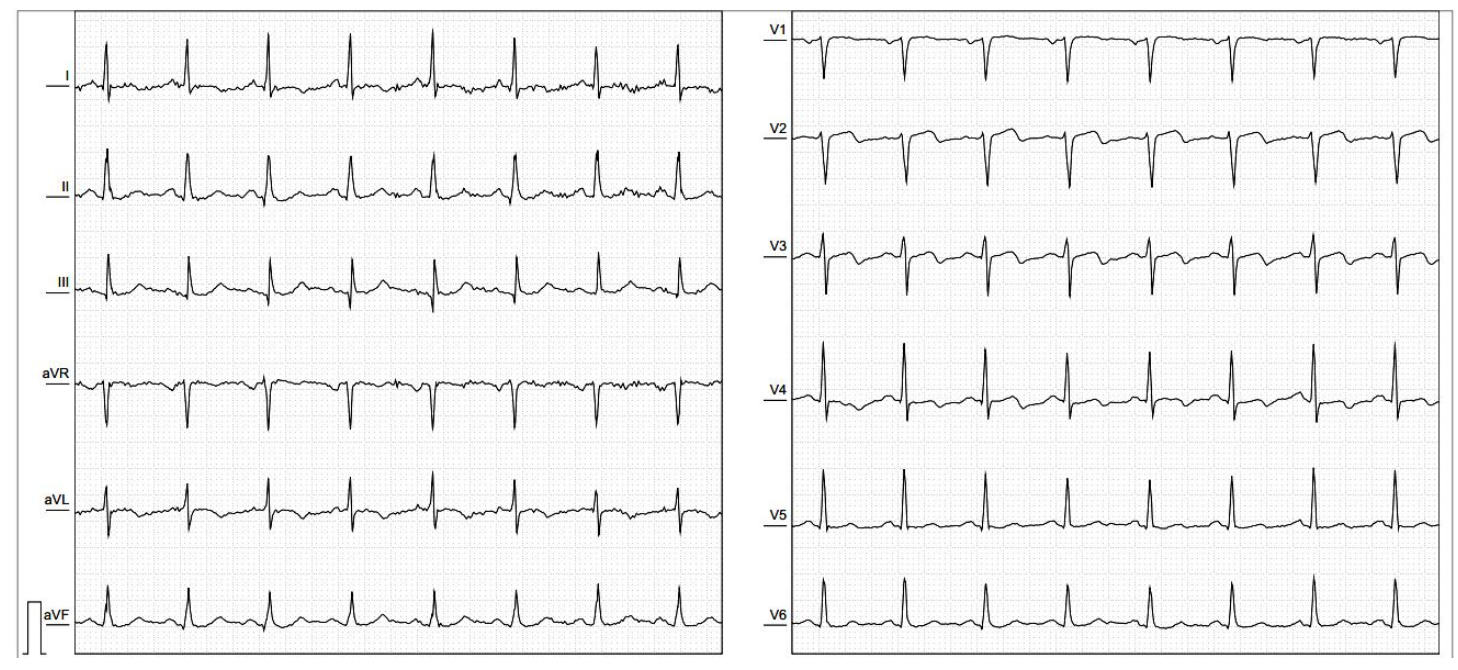

Fig. 3. ECG. Biphasic T wave in leads V2-V4. T-wave inversion in leads I and aVL
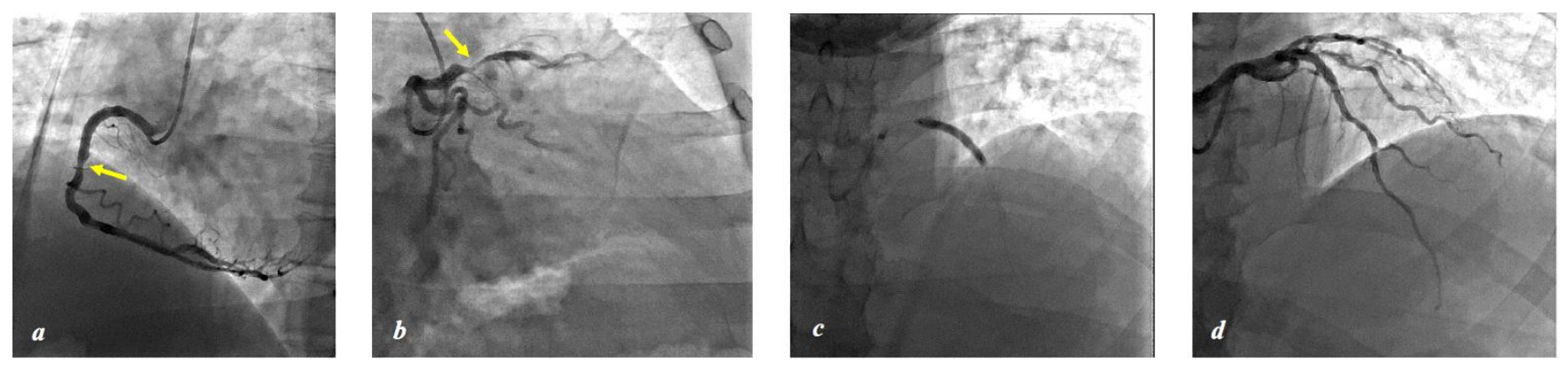

Fig. 4. Coronary angiography. Subocclusion (95\%) of the proximal LAD and stenosis $(50 \%)$ of the mid RCA Yellow arrows indicate coronary artery stenoses.

a - the right coronary artery;

$\mathrm{b}$ - the left coronary artery;

$\mathrm{c}$ - stent implantation in the proximal LAD;

$\mathrm{d}$ - blood flow after stent implantation in the LAD

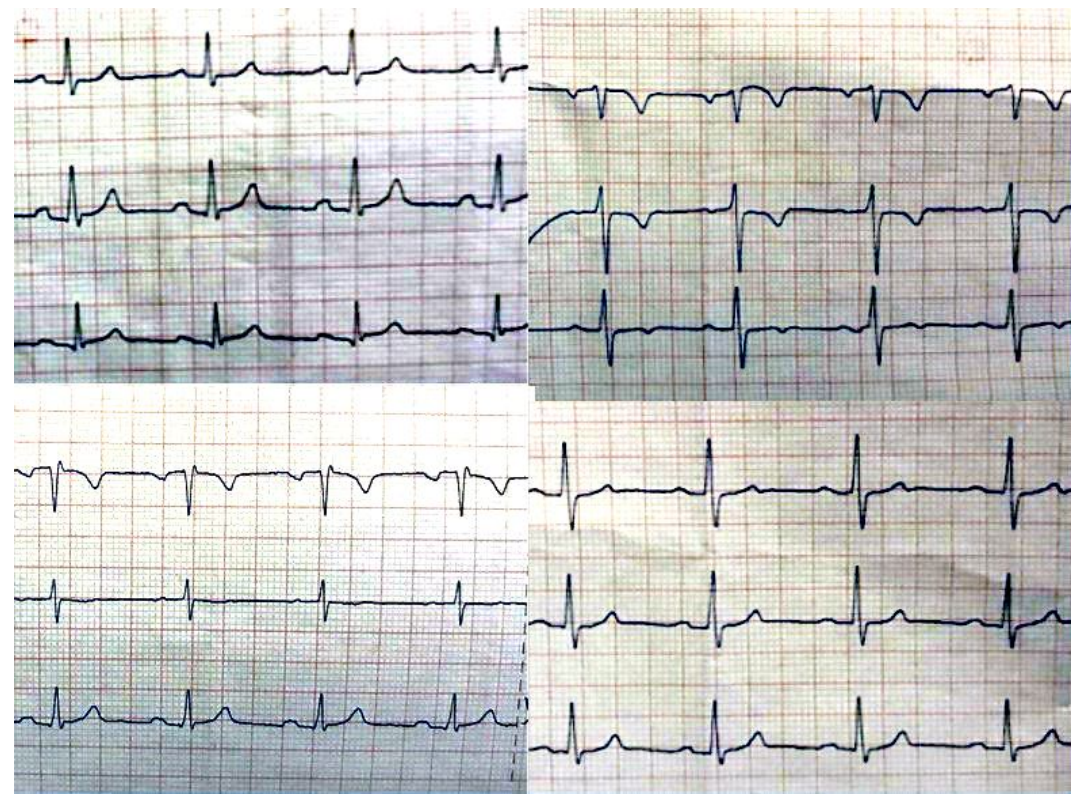

Fig. 5. ECG. T-wave inversion in leads V1-V3 

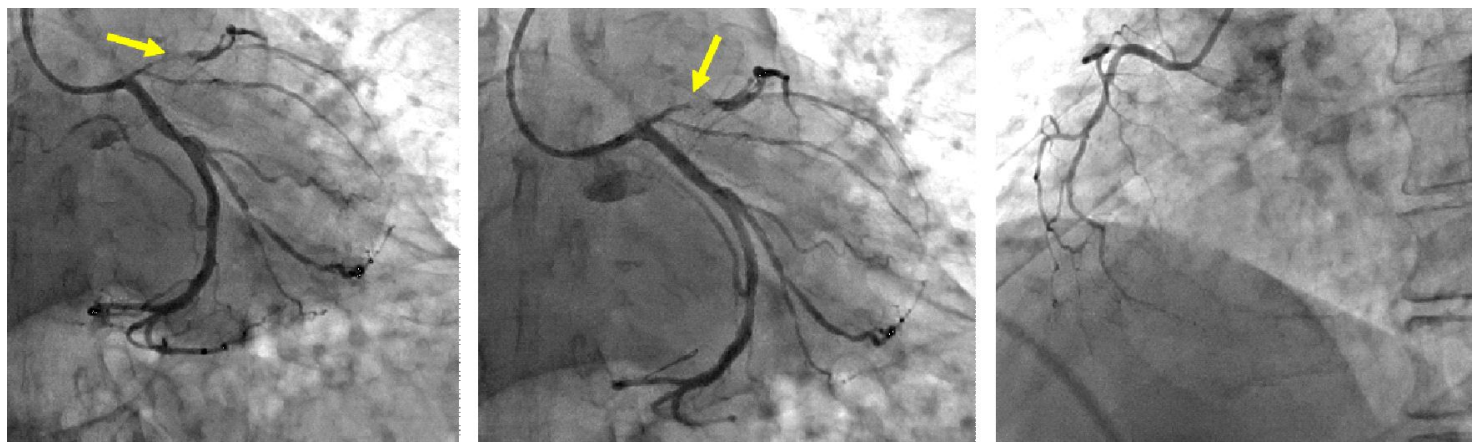

Fig. 6. Coronary angiography. Subocclusion $(95 \%)$ of the proximal LAD, a recessive right coronary artery

echocardiography. In Wellens 'syndrome, the myocardium is reported to be in a state of stunning or hibernation and does not have enough time for preconditioning, i.e. to be prepared for recurrent episodes of ischemia [8]. Elevated cardiac troponin levels have also been associated with myocardial hibernation as well. However, there is an assumption that moderate troponinemia occurs due to a certain degree of myocardial necrosis [8]. Using the speckle-tracking technique it is possible to detect regional myocardial dysfunction (prolongation of time to peak longitudinal strain, reduction in myocardial contractility, etc.), which is detected in $49 \%$ of patients with Wellens' syndrome [8]. Moreover, dyskinesia of the left ventricular segments was found to precede the occurrence of $\mathrm{T}$ wave changes.

T-wave inversion in the anterior precordial leads by $2 \mathrm{~mm}$ or more was found to have a sensitivity of $69.0 \%$ and a specificity of $89.1 \%$ for the detection of critical stenosis of the proximal LAD. The positive predictive value is $86.0 \%$ [13].

According to literature, if Wellens' syndrome is suspected, coronary angiography should be performed to detect critical stenosis or occlusion of the proximal LAD that is a mandatory sign for syndrome confirmation. However, it is not advisable to perform any exercise tests, as this may induce the development of myocardial infarction or cause death [14].

Clinical and ECG changes are known to not always be accompanied by the development of stenosis of the proximal LAD; in such cases, it is pseudo-Wellens' syndrome. There are cases when pulmonary embolism manifests itself with $\mathrm{T}$ waves in leads V2-V3 (similar to type A Wellens' syndrome) with subsequent T-wave inversion (similar to type B of this syndrome) [15]. Sometimes, such changes can be observed in young people who have been diagnosed with pulmonary embolism due to the use of neuroleptics (which increase the risk of thromboembolic complications) [16]. ECG changes typical for Wellens' syndrome have also been described in the case of acute pancreatitis; coronary angiography revealed an abnormal origin of the right coronary artery from the left sinus of Valsalva; no signs of atherosclerotic lesions were detected [17].

Consumption of cannabinoids and phencyclidine is known to lead to chest pain and ECG changes typical for Wellens' syndrome as well; however, the coronary arteries are not obstructed in such cases [18].

Changes typical for Wellens' syndrome can also be observed in left ventricular hypertrophy due long-standing arterial hypertension, even though atherosclerotic lesions of the coronary arteries are not detected [6].

We presented a case of an ECG pattern typical for Wellens' syndrome in a patient with non-obstructed coronary arteries. A 58-year-old patient $\mathrm{H}$. had episodes of chest pain and shortness of breath for one day before the visit to the doctor. The ECG revealed biphasic $\mathrm{T}$ wave in lead $\mathrm{V} 1$, inverted $\mathrm{T}$ wave in leads V2-V6 (Fig. 7). At the same time, coronary angiography did not reveal atherosclerotic lesions in the coronary arteries.

The choice of management strategy for patients with a confirmed diagnosis of Wellens' syndrome is disputable. Strategies for myocardial revascularization with PCI and CABG (including anterior minimally invasive thoracotomy) are discussed. Most authors recommend the procedure of PCI with the implantation of a DES in stenosis area [19]. At the same time, other authors prefer CABG, especially for young patients with multi-vessel disease and comorbid pathology (diabetes mellitus, chronic glomerular filtration disease, severe asthma, chronic obstructive pulmonary disease, etc.)

Medical treatment alone is not recommended for patients with Wellens' syndrome, as it does not affect the organic obstruction of the LAD.

Thus, Wellens' syndrome is a serious problem for real clinical practice. Underestimation of clinical and electrocardiographic changes, as well as delaying or neglecting coronary angiography and attempts to overcome chest pain with medications alone are dangerous because of the potential development of myocardial infarction.

\section{Conclusions}

1. Wellens' syndrome is a condition with a real threat of developing widespread myocardial infarction and even death of the patient.

2. It is advisable to include an urgent speckle-tracking echocardiographic examination in the clinical work-up program of patients with suspected Wellens' syndrome to detect segmental contractility impairment (longitudinal strain, time to peak longitudinal strain).

3. Coronary angiography is required to diagnose Wellens' syndrome and to exclude pseudo-Wellens' syndrome.

4. The preferred strategy of choice for the treatment of patients with Wellens' syndrome is PCI. CABG procedure should be used in a certain category of patients based on the Heart Team recommendations.

\section{Ethical Statement}

I hereby declare, on behalf of all authors, that the research was conducted according to the Declaration of Helsinki.

\section{Informed Consent}

I hereby declare, on behalf of all authors, that informed 


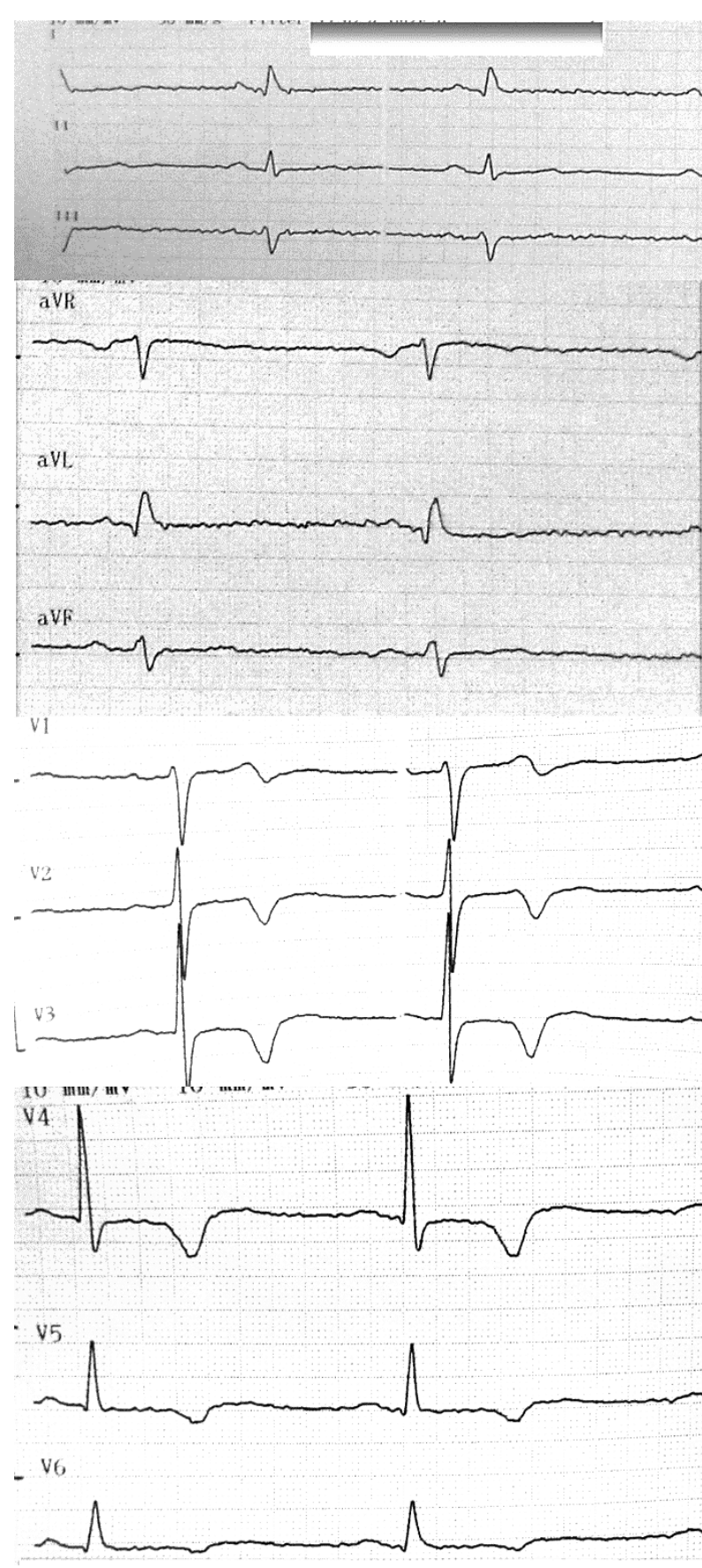

Fig. 7. ECG. Biphasic $T$ wave in leads V1, inverted $T$ waves in leads V2-V6

consent was obtained from all the patient participating in this study.

Acknowledgment of Any Presentation of This Material

I hereby declare, on behalf of all authors, that the material included in this paper has been never published.

Acknowledgment of Financial Support

This research received no specific grant from any funding agency, commercial or not-for-profit sectors.

\section{Conflict of Interest}

None.

\section{References}

1. Bahannan SA, Eltelety SM, Hassan MH, et al. Oral and Dental Health Status among Adolescents with Limited Access to Dental
Care Services in Jeddah. Dent J (Basel). 2018;6(2):15. https://doi.org/ $10.3390 / \mathrm{dj} 6020015$

2. Thomson WM, Williams SM, Broadbent JM, Poulton R, Locker D. Long-term dental visiting patterns and adult oral health. J Dent Res. 2010;89(3):307-311. https://doi.org/10.1177/ 0022034509356779

3. Kim J, Choi Y, Park S, et al. Disparities in the experience and treatment of dental caries among children aged 9-18 years: the crosssectional study of Korean National Health and Nutrition Examination Survey (2012-2013). Int J Equity Health. 2016;15:88. https://doi.org/ 10.1186/s12939-016-0377-x

4. Shvartsnau EG, Kovach IV. Condition of hard tissue of teeth and periodontal medical students. Modern Dentistry. 2015;3:9-12. [published in Russian]

5. Ehlers V, Callaway A, Wantzen S, Patyna M, Deschner J, Azrak B. Oral health of children and adolescents with or without attention deficit hyperactivity disorder (ADHD) living in residential care in rural Rhineland-Palatinate, Germany. BMC Oral Health. 2019;19(1):258. https://doi.org/10.1186/s12903-019-0948-5

6. Solyman M, Schmidt-Westhausen AM. Oral health status among newly arrived refugees in Germany: a cross-sectional study. BMC Oral Health. 2018;18(1):132. https://doi.org/10.1186/s12903018-0600-9

7. Kavaliauskien A, 'idlauskas A, hemaitien M, Slabљinskien E, Zaborskis A. Relationships of Dental Caries and Malocclusion with Oral Health-Related Quality of Life in Lithuanian Adolescents Aged 15 to 18 Years: A Cross-Sectional Study. Int J Environ Res Public Health. 2020;17(11):4072. https://doi.org/10.3390/ijerph17114072

8. Kavaliauskien A, 'idlauskas A, Zaborskis A. Association between Global Life Satisfaction and Self-Rated Oral Health Conditions among Adolescents in Lithuania. Int J Environ Res Public Health. 2017;14(11):1338. https://doi.org/10.3390/ijerph14111338

9. Semenov EI, Sennikov ON. Means and ensuring implant help young people of Ukraine. Stomatological Bulletin. 2016;3:47-49. [published in Russian]

10. Mejia GC, Elani HW, Harper S, et al. Socioeconomic status, oral health and dental disease in Australia, Canada, New Zealand and the United States. BMC Oral Health. 2018;18(1):176. https://doi.org/ 10.1186/s12903-018-0630-3

11. Nihtila A, West N, Lussi A, et al. Oral Health Behavior and Lifestyle Factors among Overweight and Non-Overweight Young Adults in Europe: A Cross-Sectional Questionnaire Study. Healthcare (Basel). 2016;4(2):21. https://doi.org/10.3390/healthcare4020021

12. Singh A, Harford J, Antunes JLF, Peres MA. Area-level income inequality and oral health among Australian adults-A populationbased multilevel study. PLoS One. 2018;13(1):e0191438. https:// doi.org/10.1371/journal.pone.0191438

13. Yamane-Takeuchi M, Ekuni D, Mizutani S, et al. Associations among oral health-related quality of life, subjective symptoms, clinical status, and self-rated oral health in Japanese university students: a cross-sectional study. BMC Oral Health. 2016;16(1):127. https:// doi.org/10.1186/s12903-016-0322-9

14. Idrees M, Hammad M, Faden A, Kujan O. Influence of body mass index on severity of dental caries: cross-sectional study in healthy adults. Ann Saudi Med. 2017;37(6):444-448. https://doi.org/10.5144/ 0256-4947.2017.444

15. Drachev SN, Brenn T, Trovik TA. Dental caries experience and determinants in young adults of the Northern State Medical University, Arkhangelsk, North-West Russia: a cross-sectional study. BMC Oral Health. 2017;17(1):136. https://doi.org/10.1186/s12903017-0426-x

16. Wang Y, Xing L, Yu H, Zhao L. Prevalence of dental caries in children and adolescents with type 1 diabetes: a systematic review and meta-analysis. BMC Oral Health. 2019;19(1):213. https://doi.org/ 10.1186/s12903-019-0903-5

17. Dental examination: basic methods. Geneva; c1989. 62p.

Received: 13.09 .2020

Revised: 27.09 .2020

Accepted: 29.09 .2020 